\title{
Language Ideologies and Transnational Migration: A Study of Cape Verdeans in Galicia
}

\author{
Nicola Bermingham
}

check for updates

Citation: Bermingham, Nicola. 2021. Language Ideologies and

Transnational Migration: A Study of Cape Verdeans in Galicia. Languages 6: 99. https://doi.org/10.3390/ languages6020099

Academic Editors: Jaine Beswick and Darren Paffey

Received: 4 February 2021

Accepted: 18 May 2021

Published: 25 May 2021

Publisher's Note: MDPI stays neutral with regard to jurisdictional claims in published maps and institutional affiliations.

Copyright: (C) 2021 by the author. Licensee MDPI, Basel, Switzerland. This article is an open access article distributed under the terms and conditions of the Creative Commons Attribution (CC BY) license (https:/ / creativecommons.org/licenses/by/ $4.0 /)$.
Department of Modern Languages and Cultures, University of Liverpool, Liverpool L69 7WY, UK; n.bermingham@liverpool.ac.uk

\begin{abstract}
Changes to the global infrastructure have contributed to the growing (linguistic) diversity of large metropolises. However, there have been calls from scholars to explore "emerging superdiversity" (DePalma and Pérez-Caramés 2018) in peripheral regions in order to fully understand the complexities and nuances of the sociolinguistics of globalisation (Wang et al. 2014; Pietikäinen et al. 2016). This article, therefore, explores language ideologies among a purposive sample of five young adults of Cape Verdean origin living in the peripheral region of Galicia, Spain, and draws on interview data to examine the ways in which multilingual migrants engage with the language varieties in their linguistic repertoire. In studying immigration from a former African colony to a bilingual European context, we can see how language ideologies from the migrant community are reflected in local ones. The sociolinguistic dynamics of Cape Verde and Galicia share many similarities: both contexts are officially bilingual (Galician and Spanish in Galicia, Kriolu and Portuguese in Cape Verde), and questions regarding the hierarchisation of languages remain pertinent in both cases. The ideologies about the value and prestige of (minority) languages that Cape Verdean migrants arrive with are thus accommodated by local linguistic ideologies in Galicia, a region which has a history of linguistic minoritisation. This has important implications for the ways in which language, as a symbolic resource, is mobilised by migrants in contexts of transnational migration. The findings of this study show how migrants are key actors in (re)shaping the linguistic dynamics of their host society and how, through their practices and discourses, they challenge long-standing assumptions about language, identity and linguistic legitimacy, and call into question ethno-linguistic boundaries.
\end{abstract}

Keywords: Galicia; Cape Verde; language ideologies; migration; peripheries

\section{Introduction}

Changes to the global infrastructure have contributed to the growing (linguistic) diversity of large metropolises. However, there have been calls from scholars to explore "emerging superdiversity" (DePalma and Pérez-Caramés 2018) in peripheral regions in order to fully understand the complexities and nuances of the sociolinguistics of globalisation (Wang et al. 2014; Pietikäinen et al. 2016). Peripheral areas are defined by their relationship (geographical, political, economic) to a perceived centre, in a relationship that is not fixed and subject to constant renegotiation (Pietikäinen and Kelly-Holmes 2013, p. 2). To date, scholarship has placed more focus on urban-central contexts than rural-peripheral ones, with peripheries largely underrepresented in sociolinguistic research. Consequently, peripheral sites (be they rural areas, peripheral areas of countries, etc.) at the 'margins' of globalisation, fall victim to a metropolitan bias and are often viewed as sites where the lessons from research into globalisation can be merely applied, rather than valuable sites for research in their own right (Wang et al. 2014). In peripheries, old relations of power are being transformed, and we can see this particularly when examining sociolinguistic changes. As Pietikäinen et al. (2016, p. 205) note, "foundational ideologies related to language, power, legitimacy and place" are being contested, challenged and rethought. In minority language contexts specifically, new patterns of migration that have come 
about due to globalisation are prompting a rethinking and re-examination of traditional linguistic paradigms, with language now no longer being a clear marker of ethnolinguistic boundaries (Pujolar and Gonzàlez 2013).

This article takes Cape Verdean migration to Galicia as its focus and addresses an analytical gap in academic scholarship by exploring migration from one peripheral context to another. It draws on language ideologies as a framework to allow for an "unpacking of how speakers understand, view and use language" (Cavanaugh 2011, p. 46), thus enabling us to better understand how speakers of Galician, from Cape Verdean backgrounds, position themselves in relation to discourses about languages and language practices, and to scrutinise how the "linguistic baggage" (Busch 2017) of Cape Verde and Galicia intersect. In studying immigration from a former African colony to a bilingual European context, we can see how language ideologies from the migrant community are reflected in local ones. The sociolinguistic dynamics of Cape Verde and Galicia share many similarities: both contexts are officially bilingual (Galician and Spanish in Galicia, Kriolu and Portuguese in Cape Verde), and questions regarding the hierarchisation of languages remain pertinent in both cases. The ideologies about the value and prestige of (minority) languages in Cape Verde are thus accommodated by local linguistic ideologies in Galicia, a region which too has a history of linguistic minoritisation. This has important implications for the ways in which language, as a symbolic resource, is mobilised by migrants.

This article will first provide a theoretical discussion of language ideologies, exploring how this analytical framework can help to shed light on the ways in which processes of transnational migration are calling into question traditional linguistic paradigms and challenging long-standing ideological complexes. The article will then examine critically the sociolinguistic contexts of Galicia and Cape Verde to highlight the intersection of colonialism, migration and language in this study. Next, the article will address methodological aspects, outlining how the study was carried out and the analytical tools that were employed. This will be followed by an analysis of the data, where three main themes emerge: linguistic purism, linguistic stigma and resistance. The discussion explores participants' ideological positionings with respect to the languages that make up their complex linguistic repertoires and examines how their ideologies are co-shaped by intersecting language ideologies in Galicia and Cape Verde. Finally, the article will conclude by drawing together the lines of enquiry to argue for an understanding of multilingualism as a phenomenon that is dynamic and deterritorialised, challenging assimilative and one-directional notions of migration.

\section{Language Ideologies}

Academic scholarship has seen an increased focus on language ideologies as an area of enquiry over the past several decades, and this has brought with it a proliferation of terminological definitions. A useful starting point for defining language ideologies is Silverstein's much-cited definition that explains language ideologies as "sets of beliefs about language articulated by users as a rationalisation or justification of perceived structure and use" (Silverstein 1979, p. 193). In this study, however, I wish to highlight that language ideologies are not just about language; rather, "they envision and enact ties of language to identity, to aesthetics, to morality and to epistemology" (Schieffelin et al. 1998, p. 3). Thus, I adopt Kroskrity's more recent definition of language ideologies as "beliefs, feelings and conceptions about language structure and use which often index the political economic interests of individual speakers, ethnic and other interest groups, and nation states" (Kroskrity 2010, p. 192) in order to emphasise how language ideologies are embedded in broader socio-cultural and socio-political contexts. Such an approach is particularly pertinent to this study, which aims to understand linguistic ideologies in a context of transnational migration. The term 'transnational migration' is used in this study to highlight that migration is not a one-directional, assimilative process, but rather a process where migrants are "simultaneously embedded in the multiple sites and layers of the transnational social fields in which they live" (Levitt and Jaworsky 2007, p. 130). 
Therefore, using language ideologies as a theoretical framework helps to illuminate how the linguistic ideologies that circulate in the Galician and Cape Verdean sociolinguistic contexts overlap and intersect.

Dominant language ideologies, which have been defined as "hegemonic beliefs and feelings about language that both reflect and serve the interests of groups with social, economic and/or political power" (Martínez 2013, p. 278), play a role in reproducing social structures and pre-existing power relations (Jaffe 2008). Dominant language ideologies should not be confused with the ideologies of dominant groups; rather, they are socially constructed complexes which are "recognised and accepted by, indeed partially constitute, the lived reality of a much broader range of groups" (Gal 1998, p. 321). Dominant ideologies, therefore, come to be naturalised, reproduced and ultimately perceived as common sense (Dubois and Boudreau 2007, p. 104). As this article will discuss, within dominant ideological frameworks, we can observe a number of ideologies at play, one of which is the ideology of the standard, defined by Lippi-Green (1997, p. 64) as "a bias toward an abstract, idealised homogenous language which is imposed and maintained by dominant institutions". The ideology of the standard essentialises language by positioning it as an unchanging system (Dubois and Boudreau 2007; Jaffe 2008). By locating legitimacy in the standard language, it serves to construct and reinforce existing linguistic hierarchies, with implications for how speakers value languages and languages practices, including their own. Milroy (2001, p. 536) explains how, in what he terms "standard language cultures", the legitimacy of the standard comes to be so well-established in the minds of speakers that rejecting it implies a rejection of the common culture and can lead to a person's views being dismissed. This has important consequences in contexts of migration, where inclusion in a common culture gains importance for social participation and social mobility.

Woolard $(2008,2016)$ invokes the contrasting ideological complexes of authenticity and anonymity to explain the ideological underpinnings of linguistic authority in modern western societies. Within the framework of authenticity, the value of a language is located in its relationship to a community and its link to geographical territory. Conversely, the ideology of anonymity holds that a language is a "neutral vehicle of communication" (Woolard 2016, p. 7) and thus belongs to no one in particular and is equally available to everyone. Woolard's framework is particularly useful for understanding how speakers of Galician from immigrant backgrounds position themselves in relation to discourses about minority languages, languages which up until recently, as this article will discuss, have largely been underpinned by the ideology of authenticity, which valorises connection to place and the territorial roots of a linguistic variety. This article, then, calls into question the ways in which language varieties are afforded value in contexts of transnational migration, and allows an exploration of how immigration is prompting a rethinking of long-standing ideological complexes. Before turning to an analysis of the data, the following section will explore the sociolinguistic contexts of Galicia and Cape Verde.

\section{Research Context: Galicia and Cape Verde}

Galicia is a peripheral region located in the north-west of Spain. It is a traditionally bilingual region where Spanish and Galician are co-official languages. However, globalisation and migratory flows have transformed Galicia into a new space of multilingualism where the languages of migrant communities have been added to the vernacular languages (Prego Vázquez and Varela 2019), making Galicia an important setting for understanding the sociolinguistic implications of transnational migration (Grosfoguel 2018). Migration to Galicia presents a salient example of intersectional oppression: Galicia is a subalternised colonial nation within the Spanish state and, as one of the most socio-economically deprived parts of Spain, has a long history of emigration which continues to the present day. Furthermore, as a relatively recent phenomenon, immigration to Galicia differs considerably from immigration to other parts of Spain: no immigrants have tried to enter Galicia via its coastline, there are few European expatriates and the agricultural sector is 
not dependent on immigrant day labourers in the same way as it is in other regions of Spain (Lamela 2018, p. 3). Immigrants account for approximately 12\% of Spain's overall population, and $3.7 \%$ of Galicia's overall population ${ }^{1}$. Nonetheless, immigrants in Galicia represent "a sudden presence of diversity that was inconceivable less than a generation ago" (Teasley et al. 2012, p. 305) and although since the economic crisis of 2008, the number of immigrants arriving in Galicia has decreased, rates of immigration are still higher than in the latter decades of the 20th century.

Galicia's sociolinguistic history is important for understanding the linguistic dynamics of the region. During the 20th century dictatorship, Spanish was the language of prestige in Galicia, used by the dominant classes and primarily in cities. Galician, conversely, was the stigmatised language of the working classes, and was associated with rural and agricultural life. Language revitalisation initiatives that have taken place in Galicia since the transition to democracy have led to an increase in positive attitudes towards Galician. Nonetheless, stigmas remain: while previously the Galician language was linked to rurality and poverty, newer stigmas surround the 'artificial' nature of standard Galician spoken by neofalantes ('new speakers' who for the most part have learned the standard, transdialectal variety of Galician through the education system), and the link between Galician and ideologies of political separatism ( $\mathrm{O}^{\prime}$ Rourke and Ramallo 2013). These stereotypes and stigmas about Galician exist in a context where Spanish continues to be positioned as the language of progress and modernity (Iglesias Álvarez 2012). Interestingly, despite these stigmas, standard Galician continues to generate the most positive attitudes when compared to regional dialectal variations (O'Rourke and Ramallo 2011; Loureiro-Rodríguez et al. 2012; Prego Vázquez and Varela 2019).

As regards language use and competence, while the population in Galicia report high levels of competence in spoken Galician ${ }^{2}$, habitual use of Spanish is increasing. In a number of Galicia's cities, Spanish is used almost exclusively, and use of Spanish is also increasing in rural areas which up until now have been Galician-speaking strongholds, in a process which Ramallo Fernández and Vázquez Ramallo Fernández and Fernández (2020), in line with Valencian sociolinguists such as Ninyoles (1971) and Aracil (1983), refer to as (socio)linguistic substitution, a term largely used as an equivalent to language shift. Moreover, Spanish is the language that is spoken most among young people, especially among young people in urban contexts. The exception to this is young people with thirdlevel education, who are slightly less likely to speak Spanish (Ramallo Fernández and Fernández 2020). Therefore, the current sociolinguistic situation in Galicia is that, in large part due to compulsory, bilingual (Galician/Spanish) education, language competence in Galician has increased over the past several decades. However, this increase in language competence has not translated into language use, and the process of language shift to Spanish continues, with important implications for the linguistic vitality of Galician.

Cape Verde is an archipelago off the west coast of Africa; it has ten islands, nine of which are currently inhabited. The Portuguese first discovered Cape Verde in 1456, and the previously uninhabited islands were subsequently populated by colonial settlers and large groups of slaves from continental Africa. Cape Verde gained independence in 1975, and the period immediately following independence saw a move towards strengthening political and economic ties with mainland Africa through, for example, joining the Economic Community of West African States (ECOWAS). However, more recently, economic links with Portugal have been revitalised. Portuguese is the official language of Cape Verde; it has high symbolic capital (Bourdieu 1986) and is used in official discourse and as the medium of instruction in schools. However, Kriolu is the first language of virtually the entire population and is considered the foundation of Cape Verdean social and cultural identity in Cape Verde and the diaspora (Duarte 1998). Since 1975, there have been several social movements that have advocated for the standardisation of Kriolu, and in the 1990s,

1 http://www.ine.es/jaxi/Tabla.htm?path=/t20/e245/p04/provi/10/\&file=0ccaa002.px, accessed on 20 May 2021.

2 https://www.ige.eu/estatico/html/gl/OperacionsEstruturais/Resumo_resultados_EEF_Galego.html\#conecemento-do-galego, accessed on 20 May 2021. 
the ALUPEC [Alfabeto Unificado para a Escrita do Caboverdiano] writing system was proposed (although it was not officially recognised by the Cape Verdean government until 2009). To this day, there continues to be a rejection of Kriolu in formal and academic domains, and political support for inclusion of Kriolu in the education system is lacking (Bermingham et al. Forthcoming).

Cape Verdean migration to Galicia dates back to the 1970s, when Cape Verdean men took up employment in the fishing industry and were later joined in Galicia by their families. The majority of Cape Verdean men in Galicia continue to work in deep-sea fishing, which means that they are usually absent from the home for extended periods of time. This matrifocal family configuration leaves the responsibility for family and community largely in the hands of women (Oca González 2018). Fernández González (2006) notes that secondand third-generation immigrants continue in large part to occupy similar positions in the labour market as their parents did: women are most likely to work in the hospitality and service sector, while men continue to work in the fishing industry.

From the above discussion, we can see the salient parallels between the sociolinguistic dynamics of Galicia and Cape Verde, two bilingual, peripheral contexts. Both Kriolu and Galician exist in minoritised positions in relation to the dominant languages of their contexts (Portuguese in Cape Verde and Spanish in Galicia). Moreover, debates about linguistic standardisation and normalisation have arisen in both contexts. While there has arguably been more extensive corpus and status planning in the Galician context (with the development of grammars and dictionaries and the establishment of language associations and a language academy), in Cape Verde there is a growing movement advocating for the inclusion of Kriolu in the education system, and the standard form of Kriolu (ALUPEC) that has been developed is used increasingly in written publications. The question of linguistic vitality, however, is an interesting point of contrast: while use of spoken Galician is decreasing (despite extensive language planning efforts), the linguistic vitality of Kriolu is high, and it continues to be the first language of virtually all the Cape Verdean population, both in Cape Verde and in the Cape Verdean diaspora. This article, then, does not argue that the sociolinguistic contexts of Cape Verde and Galicia are the same, but rather highlights how the sociolinguistic dynamics of both countries, and the parallels that can be drawn between the two, especially around linguistic minoritisation, have important implications for understanding Cape Verdean migration to Galicia, and how the linguistic ideologies of the two contexts intersect.

\section{Methodology}

The data presented in this article were collected in 2020, and form part of a larger study that looked at language practices and ideologies in Burela, a small fishing town on Galician's northern coastline with a population of approximately 10,000 people, the majority of whom are first-language Galician speakers. The study explored the language practices and ideologies of teachers and Cape Verdean students in two secondary schools, to examine the impact that ideologies of linguistic authority (Woolard 2008, 2016) can have on questions of linguistic legitimacy and identity negotiation. The research methods included classroom observations, field notes, semi-structured interviews and group interviews with 32 participants. Participants were selected following the judgment sampling method (Hoffman 2013), making use of the networks established by the researcher throughout the course of the study. This article draws on interview data from a purposive sample of five young adults. To preserve the anonymity of participants, the article provides a broad outline of their profiles: all the participants came from families who had migrated from Cape Verde to Burela; while some participants migrated to Galicia as children, two of the participants were born in Galicia. All participants were raised speaking Kriolu at home and learned Galician and Spanish through the education system and in the local community. Moreover, all the participants had undertaken higher education. In this respect, their profile was not a typical one, as numbers of Cape Verdean students from Burela progressing to higher education continues to be low. All the participants identified as first-language 
speakers of Galician and expressed very strong stances in favour of the revitalisation of Galician; as such, all interviews were conducted in Galician. The participants' positions and practices stand in contrast to the overall trends documented in Galicia which point to low levels of Galician language use among the younger sectors of the population. In this sense, as young speakers of Galician from immigrant backgrounds, the participants represent a double minority position.

Due to the travel restrictions in place during the first wave of the Covid-19 pandemic, interviews with these participants were conducted online using voice over internet protocol (VoIP) technologies Skype and Zoom. Careful consideration was given to the advantages and limitations of using these tools; while conducting interviews online cannot entirely replace face-to-face interaction, there is a growing body of research which explores this practice in qualitative research (Hanna 2012; Deakin and Wakefield 2014; Seitz 2016; Krouwel et al. 2019) and has shown VoIP-mediated interviews to be an effective qualitative research method (Lo Iacono et al. 2016). For studies such as this one, which involve people from different cultures and countries, online interviews open up new ways of contacting participants, and have the potential to make the research process more democratic by making it both more time-efficient and affordable (Lo Iacono et al. 2016). It is important to note that in this study, the researcher's established network and previous research in situ facilitated the interviewing process.

The interview protocol comprised 10-12 open-ended questions about participants language practices at home and at work, and their experiences and involvement with the Cape Verdean community in Galicia. As regards transcription, given that the analytical focus was at the content level, standard written conventions were used. The transcripts were translated from Galician into English by the author. NVivo software was used to code the interview transcripts and organise the data according to emerging themes. Critical discourse analysis (CDA) was used as an analytical tool to examine how the participants in the study constructed arguments, and how such arguments interacted with broader language ideologies. As Wodak (2001, p. 3) notes, CDA is "fundamentally concerned with analysing opaque as well as transparent structural relationships of dominance, discrimination, power and control as manifested in language." Thus, CDA was used in this study to examine the connection between language, power and ideologies. As regards positionality, in this study, language is understood as a form of social action which helps us understand how speakers' ideologies are reproduced through their language practices (Moyer 2008). Research interviews are not seen as instruments for extracting what people really think or believe, but are rather conceptualised as 'situated performances' (Heller 2008, p. 256). The focus, then, is not on questions of researcher bias, but on understanding the collaborative and co-produced nature of the data (Talmy 2010). Therefore, the data presented in this study are seen as situated, discursive performances that allow insights into how speakers position themselves in relation to discourses about language and language practices.

The following sections will turn to an analysis and discussion of the data. As has been observed in Spain's other autonomous communities (Pujolar and Gonzàlez 2013), the participants in this study often drew on dominant ideologies that valorise standard, homogenous languages, while at the same time, through their discourses and their practices, they contested and challenged ethnolinguistic categorisations and traditional linguistic paradigms about linguistic identity and legitimacy. These tensions and contradictions, and the intersecting language ideologies of Galicia and Cape Verde, will be explored, to illustrate the dynamic nature of multilingualism and challenge assimilative conceptualisations of immigration.

\section{Linguistic Purism}

In an environment that largely continues to be dominated by Spanish, there are tensions in Galicia around language shift and language loss. The linguistic contact between Galician and Spanish is often evident in the linguistic practices of Galician speakers, which can include borrowings and calques from Spanish (Gugenberger et al. 2013). Because of this, 
Galician speakers, like the participants in this study, often fear linguistic assimilation, and see contact-induced forms of Galician as reflective of an ongoing process of Castilianisation and a steppingstone towards language loss. The participants in this study frequently invoked purist ideologies when articulating their concerns about the linguistic vitality of Galician and the increasing presence of Spanish in urban and rural Galician society. In the following scenario, Mario, a 22-year-old from Cape Verde who migrated to Galicia when he was 14, reflects on the language practices of his peers and his perceptions of how language contact and change play out in Galicia.

\section{Example 1}

M: Creo que a xuventude ten mais influencia de fora, e esa influencia de fora xa cambia todo o sistema lingüístico [ ... ] se metemos as cousas de fora para dicir unha cousa que xa temos no noso idioma, acabamos a matar o noso idioma. Si metemos cousas de fora, utilizamos mais cousas de fora que de dentro.

M: I think that young people have more outside influences, and those outside influences change the whole linguistic system [ ... ] If we introduce words from outside to say something that we already have in our language, we end up killing our language. If we introduce things from outside, we will end up using more outside words than inside words.

The purist ideologies that Mario adopts are consistent with dominant models of linguistic legitimacy, where language is positioned as an essentialised object, and nonstandard and hybrid forms of language are seen as deficient and deviant. Moreover, we see how Mario deployed words from the language of biology in his argument (e.g., "killing our language"). As Jaffe (2008, p. 61) has noted, these biological metaphors, fuse "the linguistic and the biological in the image of language as species" and serve to essentialise language. Much like Mario, Andreia also expressed purist ideologies. Andreia's parents are from Cape Verde, but she and her siblings were born in Galicia. Andreia identifies as a firstlanguage speaker of Galician and expressed strong stances about Galician revitalisation and maintenance. Andreia, like many of the other participants, explained how, for her, the use of borrowings and calques from Spanish when speaking Galician is a contributing factor towards language loss.

\section{Example 2}

A: Cando tantas persoas estamos mudando ou temos esa costume de falar en castelán e logo falas en galego, en vez de buscar como esa palabra se di en galego, directamente usas o castelanismo [ ... ] entón iso de unha maneira dana a lingua porque ao final [ ... ] que non busquemos esa mesma similitude o esa mesma palabra no galego directamente, a digas en inglés o a digas en castelán, e faste entender igualmente que é importante sempre poder establecer esa comunicación entre unha persoa, dúas o varias, pero si que é verdade que ao final vas perdendo esa outra parte.

A: When so many of us are switching [between Spanish and Galician] or we're used to speaking in Spanish and then we speak in Galician and, in the end, instead of looking for what the word is in Galician, you just end up borrowing from Spanish [ ... ] in one way or another that ends up hurting the language because in the end [ ... ] if we don't look for the word in Galician, and we say it in Spanish or in English, and people understand you either way, and yes it is always important to be able to communicate with people, but it's true that you end up losing that other part.

Like Mario, Andreia, too, draws on a biological metaphor to frame her argument, using personification as a strategy to explain that, for her, codeswitching 'hurts' the Galician language. Andreia and Mario's rhetoric in this case reflects a desire to preserve an essentialised, pure form of Galician, that is free from 'outside influences', echoing research 
which highlights how code-switching and language mixing are often sanctioned within dominant ideological frameworks (Jaffe 2008).

Luís, a university student who migrated from Cape Verde to Galicia when he was 15, like the other participants, positioned codeswitching and hybrid forms of language that stemmed from language contact with Spanish as deficient. However, he made an exception for regional, non-standard varieties of Galician.

\section{Example 3}

L: Intento falar ben, tampouco me gusta por exemplo a xente que fala castrapo por exemplo.

E: Que é o castrapo?

L: O castrapo é xente que fala galego pero por exemplo mestura co castelán.

E: E que significa falar ben entón para ti?

L: A ver, falar ben pois tes, podes falar ben pero iso non significa que tes que cambiar o rexistro, non, se na túa zona se fala dunha forma pois si, por exemplo hai xente que fala galego poñendo moitas palabras en castelán e iso para min non é falar ben, usar unha palabra que nin existe en galego.

L: I try to speak properly. I don't like it when people speak castrapo, for example.

I: What's castrapo?

L: Castrapo is when people speak Galician, but they mix it with Spanish.

I: So, what does it mean to speak properly then?

L: Well, speaking properly doesn't mean that you have to change your style-if in your area people speak a certain way, then that's fine, but for example, there are people who speak Galician and use a lot of Spanish words and for me that isn't speaking properly because you're using words that don't even exist in Galician.

In this scenario, contact-induced forms of Galician are framed pejoratively, and codeswitching between Galician and Spanish is stigmatised (despite it being a widespread practice in Galicia due to the linguistic contact between the two languages). Negative attitudes towards codeswitching have been documented in many language contexts (see Dewaele and Wei 2014), with Edwards (2012) noting how terms used to describe language mixtures (such as Spanglish, Franglais and Japlish) are often used pejoratively. This also resonates with research on Kriolu and Portuguese in the Cape Verdean context. Kriolu, as a creole language, is often described as 'badly spoken Portuguese', and deviations from the European norm of Portuguese are often seen as incorrect and a source of shame (Vera-Cruz de Melo Lopes 2011).

Nonetheless, within this participant's purist framework, while codeswitching between Galician and Spanish is framed pejoratively, there is space for regional variation; he notes that "if in your area you speak in a certain way, then that's fine". Woolard $(2008,2016)$ ideological complex of authenticity is particularly useful for unpacking Luís's acceptance of regional variation in Galicia. Within the ideological complex of authenticity, the value of a language is located in its relationship to a community, and "a speech variety must be perceived as deeply rooted in social and geographic territory in order to have value" (Woolard 2016, p. 22). In this respect, regional varieties of Galician are profoundly local and are valued because of their connection to territory. Woolard's concept of sociolinguistic naturalism helps further explain these participants' rejection of hybrid forms of Galician (which Luís refers to pejoratively as castrapo): regional varieties of Galician are taken to be authoritative because they are perceived as "the natural, unmediated expression of a state of social life in the world" (Woolard 2016, p. 30) as opposed to castrapo, which is seen as the result of human intervention. 


\section{Linguistic Stigma}

Linguistic stigma emerged as a common thread in the discourses of the participants. As discussed in the introduction, dominant ideologies serve the interests of groups with social and economic power, and this can lead to the stigmatisation of language practices which may not conform to the abstract, homogenous standard language that is upheld within standard language cultures. Much like in the case of Cape Verde, where since independence debates about standardisation and officialisation of Kriolu have gained visibility (see Bermingham et al. Forthcoming), the revitalisation of Galician that took place since Spain's transition to democracy brought standard language ideologies to the fore in popular discourse in Galicia, and with it the notion of 'correctness', whereby Galician had to have a single standard norm. Furthermore, a key facet of the revitalisation process was to elevate the status of Galician by constructing it as a source of local pride and an index of local identity, which has implications for Galician speakers from immigrant backgrounds who may wish to make a claim to language ownership and Galician identity. Extensive normative debates have taken place in Galicia since the transition to democracy, and some participants in this study expressed a sense of frustration in trying to stay abreast of the outcomes of these debates. In the following example, Andreia explains how, when she writes in Galician, she will often consult the dictionary in order to ensure that her writing adheres to the most up-to-date linguistic norms. She frames her argument as part of a broader process of linguistic preservation and revitalisation.

\section{Example 4}

A: Pero a normativa do galego mudou tantísimo que, eu lle comentaba a unha das miñas compañeiras, lle digo, moitas veces estou escribindo en galego e teño aberta a páxina do dicionario galego etc. etc. porque perdemos ao final esa seguridade e esa comodidade en usar unha lingua que é nosa [ . . ] e a min é algo que, dá un pouco de medo, non, porque xustamente en esta etapa na que nós atopamos onde hai pois iso, comunidades ou zonas como A Coruña ou como Vigo onde está tan estendido o castelán, que vai chegar un punto no que a xente vai a comprender o galego (se sigue así, non) pero non vai á saber ao mellor nin falalo nin escribilo.

A: Standard Galician has changed so much that I was saying to my friend that sometimes when I'm writing in Galician I keep the dictionary open beside me [ ... ] because you lose that confidence and that security in using a language that is ours [ ... ] and for me it's something that scares me because given the current circumstances, where there are places like Vigo or Coruña where Spanish is so widespread, we're going to get to a point where people might be able to understand Galician (if we keep going the way we're going) but they won't be able to speak it or write it.

In this example, we can see an interpenetration of discourses: Andreia claims ownership of Galician and positions herself as part of a collective Galician identity (referring to Galician as "a language that is ours"), but at the same time her discourse reflects the internalisation of linguistic stigma inherent in dominant ideological frameworks when she explains how standardisation of Galician and changing norms have led her to lose confidence in her ability to write in Galician. At an individual level, using non-standard forms of a minority language can lead to linguistic insecurities and a feeling of inauthenticity. This is particularly pertinent for Galician speakers who come from an immigrant background, who may feel additional pressure to use 'authentic' linguistic varieties in order to be accepted into the minority language community.

Margarida, like Andreia, was also born in Galicia after her family migrated from Cape Verde. Margarida, too, has internalised linguistic stigma, and notes that, despite her efforts to use standard Galician, she will often use vocabulary that she describes as "not entirely correct". 


\section{Example 5}

M: O que pasa é que estamos moi influenciados polo castelán, e si que é verdade que hai palabras en galego que deberiamos empregar, e eu son a primeira que non as usa, e usamos castelanismos, hai palabras que se non existen en galego, pois vale usas un castelanismo, pero habendo a palabra en galego si que é verdade que estamos acostumados a utilizar palabras que non son del todo correctas [ ... ] así é como se perde a lingua, porque se ti estás, a ver, é o meu punto de vista, se ti estás acostumado o acostumada a meter moito castelanismo, a falar con moito, con moitas palabras incorrectas, deixas de empregar as galegas, quedas olvidándoas, e só quedan castelanismos, e de alí segues empregando castelanismos e deixas o galego de lado, entón iso si que é moi negativo porque empezas con unha palabriña e despois xa comezas á facer frases e olvídaste do galego.

M: What happens is that we're very influenced by Spanish, and it's true that there are words in Galician that we should be using, and I'm the first who doesn't use them and we borrow from Spanish, there are words that if they don't exist in Galician then, ok, use a Spanish word, but if there is a word in Galician, it's true that we're used to using words that aren't entirely correct [ ... ] and that's how you end up losing a language, because if you're used to, from my point of view, if you're used to using a lot of Spanish borrowings, using a lot of incorrect words, and you stop using the Galician words, you'll end up forgetting the Galician words and all you'll be left with is Spanish, and from there you keep using Spanish borrowings and you leave Galician to one side and it's very negative because you start with just one little word, and then it's full sentences, and then you've forgotten Galician completely.

Margarida's naturalising discourse reflects an ideology that takes for granted the legitimacy and correctness of the standard language. As Lippi-Green (1997) notes, this is a widespread and pervasive ideology which is taught in schools and reinforced across many parts of public life. Margarida's use of a modal verb ("there are words in Galician that we should be using") naturalises purist ideologies as common sense, and reflects how language ideologies, as shared beliefs, can become engrained and consequently reproduced. Given that these participants are all from immigrant backgrounds, there is an additional layer of complexity in understanding the language ideologies at play. As Milroy (2001) notes, within standard language cultures, not knowing the difference between the standard and the non-standard form can identify someone as not belonging to the community. Therefore, if you do not accept the 'common sense' linguistic ideologies of the standard culture, you position yourself on the margins and as an outsider. For immigrants who may wish to feel part of a particular community, endorsing the dominance of the standard language could be seen as a step to inclusion within the community.

The participants in this study also invoked standard language ideologies when discussing their linguistic practices in Kriolu. Although Andreia was not educated in Kriolu, she uses the written form of the language to communicate with her friends online, but feels insecure about how to write 'correctly', as she does not have access to information about standard Kriolu norms.

\section{Example 6}

A: A ver, eu escribo [en crioulo] pero si que é certo que de vez en cando estou buscando, pois iso, tanto nas miñas redes sociais, grupos de Cabo Verde e cousas así, onde poida haber como normas lingüísticas e esas cousas, porque escribir por escribir ti podes escribir, e se a persoa sabe crioulo aínda que estea mal escrito ou non, vai entender o que lle estas dicindo, non, pero si que é certo que sería moi interesante que existiran unhas normas as que puidera acceder, y tamén ensinarlle aos meus pais, porque eu creo que seria algo que lles fai moita ilusión, 
ver como a súa lingua, que sempre estivo tan mal valorada tivera unha escrita, que a xente escriba libros en crioulo...

A: I write in Kriolu but it's true that, from time to time, I look up social media, Cape Verdean groups and things like that, where there might be [Kriolu] language norms and stuff, because if you want to write, you can, and if the person reading knows Kriolu, then even if it's not written properly, they'll be able to understand what you're saying, but it would be really interesting if there were norms that I could access and also to teach my parents, because I think that it would be something that they would be really excited about, to see how their language, which was always poorly valued, does in fact have a written form, and that people write books in Kriolu ...

While standard forms of Kriolu have been elaborated, and normative debates continue to take place in Cape Verde, standard Kriolu is not as widespread as standard Galician (which is now used across domains in Galicia, notably in the education system). Thus, Andreia, who was educated in the Galician education system, positions standardisation as a way to raise the status of a minority language, and applies a similar logic to the two minority languages in her linguistic repertoire: Kriolu and Galician. It is striking that for Andreia, standardisation is not linked to potential for increased communication (she emphasises that even if she did use non-standard forms of Kriolu, people would still be able to understand her). Instead, standardisation is linked to a sense value and pride.

Luís also reflected on the practice of writing in Kriolu. His experience mirrored Andreia's in that, despite not being formally educated in standard Kriolu, he was committed to seeking out language norms of his own accord.

\section{Example 7}

L: [Escribo en Facebook] en crioulo, aínda que non nos ensinaron o crioulo na escola pero intento escribir en crioulo.

E: E como fas iso, como é a experiencia se ninguén te ensinou a escribir, como é ese proceso?

L: O crioulo se escribe mais o menos como soa, entón por iso facemos así, ademais eu de vez en cando, cando teño tempo libre, pois busco información de mais o menos como se escribe e tal.

E: E por que interésache buscar esa información?

L: Porque é a miña lingua, non, e me importa moito [ . . . ] vou buscar para mellorar o meu crioulo a escrita, porque digo, si falo, vou intentar buscar información para mellorar a miña escrita.

L: I write on Facebook in Kriolu, even though they didn't teach us Kriolu in school, but I try to write in Kriolu.

I: And how do you do that? What's it like trying to write if you were never taught? What is that process like?

L: Kriolu is written more or less the same way that it sounds, so that's what we do, and then also every now and then when I have free time I look up information on how to write it.

I: And why are you interested in looking up that information?

L: Because it's my language and it matters a lot to me [ . . . ] and I want to improve my written Kriolu because if I'm able to speak then I want to also find information so as to improve my writing.

For Luís, using standard Kriolu is linked to a sense of pride in his language and a desire to 'improve' it by using the standard form. As with Andreia, the key issue at stake is not comprehensibility-he highlights that being understood is not a problem, as Kriolu can be written phonetically (and indeed emerging research points to the increasing use 
of written Kriolu in social media (Beckert 2020)). What we see here is an interpenetration of ideologies: standard, dominant ideologies (which value homogenous, written forms) come through strongly among those that advocate for minority languages. As Woolard and Schieffelin (1994) highlight, minority language revitalisation movements often draw on the same ideological structures that have led to their oppression to begin with, such as the ideologies of linguistic purism and authenticity that we see in this study.

\section{Resistance}

Resistance emerged strongly as a theme in the discourses of this group of participants. While the participants drew frequently on discourses of linguistic purity when discussing their language practices, such discourses were then subsequently deployed to construct counter-hegemonic arguments. Catarina, a writer in her 30s who was born in Cape Verde but migrated to Galicia with her family when she was of primary school age, articulated how, for her, minority language revitalisation was a way of resisting colonialism, and the linguistic hegemony associated with globalisation.

\section{Example 8}

C: Eu creo que é polo colonialismo [ . . ] [o criol] era como unha forma de resistencia, e esta forma de resistencia acabou pois alargándose non, pois en Galicia [o galego] pois é unha lingua de resistencia, aínda que pasou un pouco ao contrario, impúxose o castelán, e en Cabo Verde tamén, porque se impuxo o portugués, pero non sei porque en Galiza quedou ese prexuízo non de que as persoas campesiñas son os que falan o galego [ . . . ] e penso que é como un monopolio non, que pasa co o inglés tamén, que monopoliza todo [ ... ] é unha riqueza incalculable e poder ter outras linguas no que nos expresemos, tanto oral como escrita, eu véxoo fundamental.

C: I think it's linked to colonialism [ . . . ] Kriolu is like a form of resistance, and that form of resistance has continued, and Galician is a language of resistance too, although the opposite happened and Castilian was imposed, and in Cape Verde Portuguese was also imposed, but I don't know why in Galicia there is still that prejudice that it is people from the countryside who speak Galician. [ . . ] I think that it's like a monopoly, you see it happen with English too, it just monopolises everything [ ... ] and it's an invaluable source of wealth to have other languages in which to express yourself, be it spoken or written language, I think it's very important.

She further highlighted the similarities she perceived between the linguistic contexts of Galicia and Cape Verde, and explained her motivations for using Kriolu in her writing:

\section{Example 9}

C: [Gústame escribir en crioulo] porque o sinto necesario, e a parte hai tamén en Cabo Verde como unha censura ao crioulo bastante grande, que o sinto tamén co galego, non, e son cousas bastante parecidas [ ... ] a xente o está recoñecendo como idioma, a xente está escribindo en crioulo para que quede constancia de que si que se pode, e si que hasta fai nada non había, como se dice, unha escrita común do crioulo feita, e fai nada pois como que xa posto un estándar de como debería ser escrito ese crioulo, entón como que estamos en ese proceso de recoñecernos como é o noso idioma.

C: [I like to write in Kriolu] because I feel it's necessary, because in Cape Verde there is like a censorship of Kriolu, it's fairly significant, and I feel it too with Galician, they're fairly similar situations [ ... ] people are starting to recognise Kriolu as a language and people are writing in Kriolu so that there's evidence that it is possible [to write in Kriolu], because up until recently there wasn't a, how do you call it ... a common way to write Kriolu hadn't been developed, but now that there's a standard as to how Kriolu should be written, well we're in that process of recognising our own language. 
Catarina writes in Kriolu (even though earlier in the interview she notes that she would find it easier to write in Galician or Spanish) a way of resisting the 'censorship' of minority languages. Much like what we saw in Andreia's comments, for Catarina, having access to a standard form or Kriolu is an important part of an ongoing process of valuing the Kriolu language. Thus, through her language practices, Catarina challenges traditional power structures and resists the hegemony of global languages. What is interesting here is that we can see how discourses of linguistic purity can be deployed to support counterhegemonic arguments. The comments from Andreia, below, where she discusses regional variation in Galicia, exemplify the tensions between the dominant, standard language ideologies and the counter-hegemonic ideologies that participants drew on.

\section{Example 10}

A: Semella tamén algo súper complicado porque logo hai digamos todas esas formas do galego, na parte do norte se dice dunha maneira, no centro noutra e no sur noutra e é como, cal é o galego, entre comillas, o galego verdadeiro é de todas, non, pero cando ti queres facer un escrito dende un punto de vista mais formal, pois tes un pouco esas complicacións, non?

A: It's really complicated because [in addition to standard Galician] there are other forms of Galician in the north where they say things in a certain way, and in the centre they say them another way and in the south another. So, what, in inverted commas, is real Galician? I mean, real Galician is everyone's Galician, but when you want to write something formal, well then it becomes a bit complicated, right?

Andreia reflects on regional variation in Galicia and concludes by saying that "real" Galician is "everyone's", locating legitimacy in the entire community of speakers. It is particularly striking in this instance that in the original Galician transcript she says "o galego verdadeiro é de todas". In line with current debates in feminist linguistics, Andreia deliberately uses the feminine generic and breaks away from the established practice in Galician (and Spanish) to use the masculine generic to refer to a mixed group, thus challenging the pre-existing power structures that dominant ideologies often serve to reinforce and reproduce. Nonetheless, Andreia explicitly acknowledges the tensions that surround the linguistic legitimacy of Galician, explaining how she feels that these tensions are heightened in written expression. This is consistent with research that has observed that standard language ideologies in relation to written language are stronger than in relation to spoken language (Fenigsen 1999; Woolard 2016, p. 155). Margarida's discourses reflected similar tensions about the legitimacy of Galician.

\section{Example 11}

M: Non falamos o galego normativo, falamos o noso galego da nosa area, do noso bloque. Non é un galego totalmente correcto e normativo pero bueno eu sempre digo que se fai o que se pode, o único galego que está mal é o que non se fala.

M: The Galician that we speak isn't standard Galician, we speak our own Galician, from our own area, our own region. It's not entirely correct or standard, but what I always say is that the only bad Galician is the one that isn't spoken.

Margarida notes that the variety of Galician that she speaks is not "entirely correct or standard" and she locates legitimacy in the standard variety. Nonetheless, she then deploys a more inclusive discourse by stating that "the only bad Galician is the one that isn't spoken". We therefore see intertwined discourses about linguistic legitimacy emerge in the strong tendency for participants to draw on discourses of linguistic purism while at the same time deploying counter-hegemonic discourses of resistance.

Discourses of resistance also came through strongly in the data when participants discussed their motivations for speaking Galician. As already noted, use of Galician is declining in Galicia, especially among young people. As such, these participants are going against overall language trends, and their speaking Galician stands out as a marked 
choice. In the following example, Andreia explains her motivations for speaking Galician. Andreia challenges the links between minority languages and territory, and explains how, through her linguistic practices, she challenges preconceptions about who is a legitimate speaker of Galician and who has legitimate access to the language. By using Galician as a "tool to educate people" and "to tear down prejudices", Andreia transforms linguistic and cultural practices in Galicia and demonstrates how, due to increased mobility, territorialised language practices and identities can become more fluid.

\section{Example 12}

A: Tamén para moitas veces derribar eses prexuízos que poida haber porque hai moitísima xente que sigue vendo, pois iso, unos rasgos o unha cor de pel e sigue directamente vinculándoo a migración, que eu procedo da inmigración, non, pero a todas claras son galega dende hai moitísimos anos e de algunha maneira iso serve tamén, hai que usalo tamén como unha ferramenta para educar non?

A: [I'm motivated to speak Galician] to tear down the prejudices that people might have, because there are still a lot of people who see certain characteristics, a certain colour of skin, and they still link it directly to migration, and yes I come from an immigrant background, but by all means I've been Galician for a very long time, so in some ways speaking Galician is useful in that sense, you have to use it as a tool to educate people.

Mobility and migration are motivating a rethinking and reconceptualising of traditional linguistic paradigms, and in this study we see how speakers of Galician from immigrant backgrounds are instrumental in challenging and transforming such paradigms. As with research which has indicated a shift towards the 'de-ethnicisation' of Catalan, whereby "language users have become so diverse that the language can no longer operate as a practical index of a specific group" (Pujolar and Gonzàlez 2013, p. 140), participants like Andreia contribute to similar processes in the Galician context and shift linguistic authority away from the ideological complex of authenticity. Andreia further explains:

\section{Example 13}

A: Home creo que é porque hai moita xente que non está acostumada a ver persoas racializadas falando en galego, e porque as cidades como Coruña, excepto algúns contextos, a maioría da poboación fala en castelán, entón sigue habendo ese prexuízo eu creo é do galego moi ligado ao ámbito rural ou un pouco, non sei, ese tipo de cousas, eu creo que sigue habendo, que pouco a pouco se vai de algunha maneira derribando ese ideario pero sigue alí fortemente raizado eu creo.

A: There are a lot of people who aren't used to seeing people of colour speaking Galician, and because there are cities like Coruña where, except for in certain contexts, most of the population speaks in Spanish, so there continues to be this prejudice where Galician is linked to rurality and this kind of thing, and I think it still is, and bit by bit we try to break this down, even though it's deeply rooted I think.

This was further echoed by Catarina, who noted that "eu creo que teñen ese preconceito de que os corpos negros son sempre corpos migrantes entón se quedan chocados, lles choca que unha persoa negra pois fale o castelán ou fale moi ben o galego, sabes?" ["People have these preconceived ideas that black people are always migrants, so they end up quite shocked when a black person speaks Spanish or speaks Galician really well, you know?"] From these participant's comments, we can see that the ethno-national paradigm still holds strong. Both Andreia and Catarina acknowledge that to a certain extent their speaking Galician is seen as exceptional and contradictory to traditional expectations. Thus "the ethnonational linguistic paradigm remains a referent even as it gets constantly contested" (Pujolar and Gonzàlez 2013, p. 145), and we see how this plays out in Andreia and Catarina's discourses. 


\section{Conclusions}

The ways in which globalisation and transnational migration are calling into question traditional linguistic paradigms are of key concern to sociolinguistic scholarship. To date, greater focus has been placed on researching large, urban contexts than smaller, peripheral ones. Researching peripheral sites is therefore necessary to fully understand the nuances and complexities of contemporary sociolinguistic processes. This article has focused on two peripheral contexts, Galicia and Cape Verde, both of which have a history of linguistic minorisation, in order to gain insights into how languages (and minority languages in particular) are afforded value in contexts of transnational migration.

The study found divergent and often conflicting ideologies coming to the fore in the discourses of participants: on the one hand, a dominant ideological framework came through strongly in the data, with participants tacitly accepting the dominance of the standard language and drawing on discourses of linguistic purism. On the other hand, however, the participants' discourses reflected counter-hegemonic ideologies which called into question the legitimacy of the standard language and conceptualised minority language revitalisation as a form of resistance. The dominant ideologies that were reflected in the discourses of the participants are consistent with research that has found that minority language revitalisation initiatives can often become normative and prescriptive, with Wang et al. (2014) cautioning that such prescriptivism can, in effect, doubly marginalise speakers whose linguistic practices do not adhere to the prescribed norms, and this indeed was reflected in the discourses of participants where linguistic stigma emerged as a strong theme. However, echoing research that has highlighted how language ideologies are "always full of internal contradictions" (Blommaert and Verschueren 1998, p. 36), the participants also overtly contested dominant models of linguistic legitimacy and explicitly invoked discourses of decolonisation, drawing links between the position of Galicia as a subalternised nation within the Spanish state, and postcolonial Cape Verde. As such, this study found that Galician language revitalisation was framed as an inclusive process where linguistic variation was embraced, and where minority languages were positioned as a tool for resisting dominant structures.

I argue that the explanation for these interweaving ideologies is as follows: Cape Verde is a postcolonial society whose sociolinguistic dynamics are strongly diglossic-Portuguese is the language of prestige and is used in formal (especially written) contexts, while Kriolu is primarily an oral language used informal settings. As such, the participants in the study, all of whom come from a Cape Verdean background, have internalised dominant models of linguistic legitimacy which hold strong both in Cape Verde and Galicia. Moreover, the linguistic hierarchisation that the participants in this study have experienced contributes to their linguistic awareness of the sociolinguistic dynamics of Galician society. Thus, it could be contended that the participants in the study, who come from a postcolonial context, demonstrate favourable attitudes towards the Galician language as they link minority language revitalisation and maintenance to processes of decolonisation, and position the Galician language as a tool for resisting linguistic hegemony.

The findings of this study also indicate that both Cape Verde and Galicia operate as standard language cultures (Milroy 2001), and this is reflected in the dominant ideological framework that emerged in the discourses of the participants. Hybrid language practices and linguistic contact were framed pejoratively, and linguistic purism was invoked as part of a broader strategy for resisting the hegemony of Spanish (and to a lesser extent English). As Spanish continues to be the dominant language across many domains in Galicia, the participants frequently expressed their concerns about the decline in the number of Galician speakers and the future linguistic vitality of Galician; in these instances, linguistic purism and prescriptivism were seen as ways of countering processes of linguistic assimilation and resisting the hegemony of global languages. This study also aligns with previous research which has found that migrants, rather than identifying with the nation state, (which in many cases presents itself as representative of a specific ethno-national group) often may be more favourable to developing a locally defined sense of belonging in the 
host country (Koopmans 2004, p. 450). In this study, the participants overtly rejected the Spanish language and Spanish identity but were happy to claim Galician identity and ownership of the Galician language.

The findings of this study contribute to current scholarly debates which call for a rethinking of social actors in minority language contexts as either compliant or resistant to dominant language ideologies (Pietikäinen et al. 2016, p. 198) and instead highlight the multifaceted nature of language ideologies, and the internal contradictions that can emerge in people's discourses. Furthermore, this study has contributed to a criticism of traditional views of immigrants as "uprooted individuals and communities" (De Fina 2016, p. 164), and contested the notion of immigration as a one-directional process which involves immigrants assimilating into the culture of their host country. Within such traditional frameworks, processes of migration are conceptualised in false binaries such as 'national and transnational' or 'territorial and deterritorialised', which fail to capture the complex processes at play in contexts of transnational migration (De Fina 2016). This study has shown, instead, how migrants are key actors in (re)shaping the linguistic dynamics of their host society and how, through their practices and discourses, they challenge long-standing assumptions about language, identity and linguistic legitimacy, and call into question ethno-linguistic boundaries.

Funding: This research received no external funding.

Institutional Review Board Statement: The study was conducted according to the guidelines of the Declaration of Helsinki, and approved by the Ethics Committee of the University of Liverpool in 2020 .

Informed Consent Statement: Informed consent was obtained from all subjects involved in the study.

Data Availability Statement: The data presented in this study are available on request from the corresponding author. The data are not publicly available due to privacy reasons.

Conflicts of Interest: The author declares no conflict of interest.

\section{References}

Aracil, Lluís Vicent. 1983. Dir La Realitat. Barcelona: Edicions Paisos Catalans.

Beckert, Ronny. 2020. Kabuverdianu no sistema educativo em Cabo Verde e o seu status em relação ao português. Linguagem E Ensino 23: $1224-47$.

Bermingham, Nicola, Renée DePalma Úngaro, and Luzia Oca González. Forthcoming. The 'access paradox': Discourses around bilingual education in Cabo Verde. Modern Languages Open.

Blommaert, Jan, and Jef Verschueren. 1998. The role of language in European nationalist ideologies. In Language Ideologies: Practice and Theory. Edited by Bambi B. Schieffelin, Kathryn A. Woolard and Paul V. Kroskrity. New York and Oxford: Oxford University Press, pp. 189-210.

Bourdieu, Pierre. 1986. The forms of capital. In Handbook of Theory and Research for the Sociology of Education. Edited by John G. Richardson. New York: Greenwood, pp. 241-58.

Busch, Brigitta. 2017. Expanding the Notion of the Linguistic Repertoire: On the Concept of Spracherleben-The Lived Experience of Language. Applied Linguistics 38: 340-58. [CrossRef]

Cavanaugh, Jillian R. 2011. Language Ideologies and Language Attitudes: A Linguistic Anthropological Perspective. In Language Variation-European Perspectives IV. Edited by Peter Auer, Javier Caro Reina and Göz Kaufmann. Amsterdam: John Benjamins, pp. 45-55.

De Fina, Anna. 2016. Linguistic practices and transnational identities. In The Routledge Handbook of Language and Identity. Edited by Siân Preece. London: Routledge, p. 16.

Deakin, Hannah, and Kelly Wakefield. 2014. Skype interviewing: Reflections of two PhD researchers. Qualitative Research 14: 603-16. [CrossRef]

DePalma, Renée, and Antía Pérez-Caramés. 2018. Preface. In Galician Migrations: A Case Study of Emerging Super-Diversity. Edited by Renée DePalma and Antía Pérez-Caramés. Berlin: Springer, pp. ix-xix.

Dewaele, Jean-Marc, and Li Wei. 2014. Attitudes towards code-switching among adult mono- and multilingual language users. Journal of Multilingual and Multicultural Development 35: 235-51. [CrossRef]

Duarte, Dulce Almada. 1998. Bilinguismo Ou Diglossia? As Relações de Força Entre o Crioulo e o Português Na Sociedade Cabo-Verdiana. Praia: Spleen. 
Dubois, Lise, and Annette Boudreau. 2007. Discourses on language preservation along the shores of the Baie Sainte-Marie. In Discourses of Endangerment: Ideology and Interest in the Defence of Languages. Edited by Alexandre Duchêne and Monica Heller. London and New York: Continuum, p. 99.

Edwards, John. 2012. Multilingualism: Understanding Linguistic Diversity. New York: Continuum.

Fenigsen, Janina. 1999. "A broke-up mirror": Representing Bajan in print. Cultural Anthropology 14: 61-87. [CrossRef]

Fernández González, Luzia. 2006. La dialéctica de la inclusión versus exclusión de los inmigrantes: Retórica y realidad. In Estudios Sobre Flujos Migratorios En Perspectiva Educativa y Cultural. Edited by Miguel Anxo Santos Rego. Granada: Grupo Editorial Universitario.

Gal, Susan. 1998. Multiplicity and contestation among linguistic ideologies. In Language Ideologies: Practice and Theory. Edited by Kathryn Woolard and Bambi Schieffelin. Oxford: Oxford University Press, pp. 317-31.

Grosfoguel, Ramón. 2018. Foreword. In Galician Migrations: A Case Study of Emerging Super-Diversity. Edited by Renée DePalma and Antía Pérez-Caramés. Berlin: Springer, pp. v-viii.

Gugenberger, Eva, Henrique Monteagudo, and Gabriel Rei-Doval. 2013. Contacto de Linguas, Hibrididade, Cambio: Contextos, Procesos e Consecuencias. Santiago de Compostela: Consello da Cultura Galega.

Hanna, Paul. 2012. Using internet technologies (such as Skype) as a research medium: A research note. Qualitative Research 12: $239-42$. [CrossRef]

Heller, Monica. 2008. Doing Ethnography. In The Blackwell Guide to Research Methods in Bilingualism and Multilingualism. Edited by Li Wei and Melissa G. Moyer. Oxford: Blackwell Publishing Ltd., pp. $249-62$.

Hoffman, Michol. 2013. Sociolinguistic Interviews. In Research Methods in Sociolinguistics: A Practical Guide. London: Wiley, pp. $25-41$.

Iglesias Álvarez, Ana. 2012. Actitudes e prexuízos lingüísticos en Galicia. A súa influencia nos usos. A letra miúda- $n^{\circ} 1-R e v i s t a ~ d e$ sociolingüística da CGENDL, 1-18.

Jaffe, Alexandra. 2008. Discourses ot endangerment: Contexts and consequences of essentializing discourses. In Discourses of Endangerment: Ideology and Interest in the Defence of Languages. Edited by Alexandre Duchêne and Monica Heller. New York: Continuum, p. 57.

Koopmans, Ruud. 2004. Migrant mobilisation and political opportunities: Variation among German cities and a comparison with the United Kingdom and the Netherlands. Journal of Ethnic and Migration Studies 30: 449-70. [CrossRef]

Kroskrity, Paul V. 2010. Language Ideologies-Evolving Perspectives. In Language Use and Society (Handbook of Pragmatics Highlights). Edited by Jürgen Jaspers. Amsterdam and Philadelphia: John Benjamins.

Krouwel, Matthew, Kate Jolly, and Sheila Greenfield. 2019. Comparing Skype (video calling) and in-person qualitative interview modes in a study of people with irritable bowel syndrome-an exploratory comparative analysis. BMC Medical Research Methodology 19: 1-9. [CrossRef]

Lamela, Carmen. 2018. From a Land of Emigrants to a Land of Immigrants? The Complex Realities Behind a Common Perception. In Galician Migrations: A Case Study of Emerging Super-Diversity. Edited by Renée DePalma and Antía Pérez-Caramés. Berlin: Springer, pp. 1-12.

Levitt, Peggy, and B. Nadya Jaworsky. 2007. Transnational Migration Studies: Past Developments and Future Trends. Annual Review of Sociology 33: 129-56. [CrossRef]

Lippi-Green, Rosina. 1997. English with an Accent: Language, Ideology, and Discrimination in the United States, 2nd ed. Oxon: Routledge.

Lo Iacono, Valeria, Paul Symonds, and David H. K. Brown. 2016. Skype as a tool for qualitative research interviews. Sociological Research Online 21: 103-17. [CrossRef]

Loureiro-Rodríguez, Verónica, May M. Boggess, and Anne Goldsmith. 2012. Language Attitudes in Galicia: Using the MatchedGuise Test Among High School Students. Journal of Multilingual and Multicultural Development 34: 136-53. Available online: http: / / www.tandfonline.com/doi/abs/10.1080/01434632.2012.729591 (accessed on 8 February 2013).

Martínez, Ramón Antonio. 2013. Reading the world in Spanglish: Hybrid language practices and ideological contestation in a sixth-grade English language arts classroom. Linguistics and Education 24: 276-88. [CrossRef]

Milroy, James. 2001. Language ideologies and the consequences of standardization. Journal of Sociolinguistics 5: 530-55. [CrossRef]

Moyer, Melissa G. 2008. Research as Practice: Linking Theory, Method, and Data. In The Blackwell Guide to Research Methods in Bilingualism and Multilingualism. Edited by Li Wei and Melissa G. Moyer. Oxford: Blackwell Publishing Ltd., pp. 18-32.

Ninyoles, Rafael Lluís. 1971. Idioma y Conflict. Revista española de la opinión pública 26: 159-82. [CrossRef]

O'Rourke, Bernadette, and Fernando F. Ramallo. 2011. The native-non-native dichotomy in minority language contexts. Comparisons between Irish and Galician. Language Problems E Language Planning 35: 139-59.

O'Rourke, Bernadette, and Fernando Ramallo. 2013. Competing ideologies of linguistic authority amongst new speakers in contemporary Galicia. Language in Society 42: 287-305. [CrossRef]

Oca González, Luzia. 2018. Cape Verdeans in Burela: Women's Empowerment Through Gendered Cultural Practices. In Galician Migrations: A Case Study of Emerging Super-Diversity. Edited by Renée DePalma and Antía Pérez-Caramés. Berlin: Springer, pp. 193-206.

Pietikäinen, Sari, Alexandra Jaffe, Helen Kelly-Holmes, and Nikolas Coupland. 2016. A view from the periphery. In Sociolinguistics from the Periphery: Small Languages in New Circumstances. Cambridge: Cambridge University Press, pp. 194-207.

Pietikäinen, Sari, and Helen Kelly-Holmes. 2013. Multilingualism and the Periphery. In Multilingualism and the Periphery. Edited by Sari Pietikäinen and Helen Kelly-Holmes. New York and Oxford: Oxford University Press, pp. 1-16. 
Prego Vázquez, Gabriela, and Luz Zas Varela. 2019. Unvoicing practices in classroom interaction in Galicia (Spain): The (de)legitimization of linguistic mudes through scaling. International Journal of the Sociology of Language 2019: 77-107. [CrossRef]

Pujolar, Joan, and Isaac Gonzàlez. 2013. Linguistic "mudes" and the de-ethnicization of language choice in Catalonia. International Journal of Bilingual Education and Bilingualism 16: 138-52. [CrossRef]

Ramallo Fernández, Fernando, and Martín Vázquez Fernández. 2020. Condiciones del bilingüismo en la Galicia actual. In El español en el mundo. Anuario del Instituto Cervantes. Instituto Cervantes: Available online: https://cvc.cervantes.es/lengua/anuario/ anuario_20/ramallo_vazquez/p03.htm (accessed on 1 May 2021).

Schieffelin, Bambi B., Kathryn A. Woolard, and Paul V. Kroskrity, eds. 1998. Language Ideologies: Practice and Theory. New York and Oxford: Oxford University Press.

Seitz, Sally. 2016. Pixilated partnerships, overcoming obstacles in qualitative interviews via Skype: A research note. Qualitative Research 16: 229-35. [CrossRef]

Silverstein, Michael. 1979. Language structure and linguistic ideology. In The Elements: A Parasession on Linguistic Units and Levels. Edited by Paul R. Clyne, William F. Hanks and Carol L. Hofbauer. Chicago: Chicago Linguistic Soc, pp. 193-247.

Talmy, Steven. 2010. Qualitative Interviews in Applied Linguistics: From Research Instrument to Social Practice. Annual Review of Applied Linguistics 30: 128-48. [CrossRef]

Teasley, Cathryn, Concepción Sánchez-Blanco, and Renée Depalma. 2012. Postcolonial Perspectives, Social Integration and Cultural Diversity vis-à-vis Neoliberal Policies and Practices in Galizan Schooling. Power and Education 4: 303-14. [CrossRef]

Vera-Cruz de Melo Lopes, Amália Maria. 2011. As Línguas de Cabo Verde: Uma Radiografia Sociolinguística. Doctoral thesis, Universidade de Lisboa, Lisboa, Portugal.

Wang, Xuan, Massimiliano Spotti, Kasper Juffermans, Leonie Cornips, Sjaak Kroon, and Jan Blommaert. 2014. Globalization in the margins: Toward a re-evaluation of language and mobility. Applied Linguistics Review 5: 23-44. [CrossRef]

Wodak, Ruth. 2001. What CDA Is About-A Summary of Its History, Important Concepts and Its Developments. In Methods of Critical Discourse Analysis. Edited by Ruth Wodak and Michael Meyer. Thousand Oaks: SAGE Publications, pp. 1-13.

Woolard, Kathryn. 2008. Language and Identity Choice in Catalonia: The Interplay of Contrasting Ideologies of Linguistic Authority. In Lengua, Nación e Identidad. La Regulación Del Plurilingúismo En España y América Latina. Edited by Kirsten Süselbeck, Ulrike Mühlschlegel and Peter Masson. Madrid: Iberoamericana, pp. 303-23.

Woolard, Kathryn. 2016. Singular and Plural: Ideologies of Linguistic Authority in 21st Century Catalonia. New York: Oxford University Press.

Woolard, Kathryn A., and Bambi B. Schieffelin. 1994. Language Ideology. Annual Review of Anthropology 23: 55-82. [CrossRef] 